\title{
熱音響自励振動に関する数值解析
}

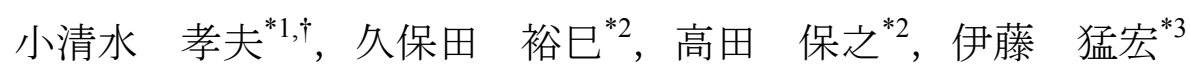

\section{Numerical Analysis of Thermoacoustic Self-exited Oscillation}

\author{
Takao KOSHIMIZU $^{* 1, \dagger}$, Hiromi KUBOTA ${ }^{* 2}$, Yasuyuki TAKATA ${ }^{* 2}$ and Takehiro ITO ${ }^{* 3}$
}

\begin{abstract}
Synopsis: A numerical analysis has been performed to investigate the behavior of gas when thermoacoustic self-exited oscillation begins to be generated and to clarify the influence of heat input at a heater at the time of generating self-exited oscillation. The simplest device in which a regenerator is inserted into a tube is applied to the physical model. Transient onedimensional equations of continuity, momentum and energy are solved utilizing a TVD scheme. It was found that the amount of heat input is related to the initial infinitesimal oscillation, which is considerably important as a disturbance factor for generation of real self-exited oscillation. It was also found that the infinitesimal oscillation is generated by temporally discontinuing heat input.

Keywords: thermoacoustic phenomenon, self-exited oscillation, numerical analysis
\end{abstract}

\section{1. はじめに}

近年，熱音響現象 ${ }^{1)}$ を利用した熱音響デバイスの実用化 に向けて, 多くの研究が行われるようになってきた.さら に，振動流中の物理量を計測する技術 ${ }^{2)}$ も確立されてきた ため, 今後も性能の効率化, 新しい型式の開発など多くの 実験的研究が盛んに行われると予想される. 一方, 数值解 析 3)-7)もパルス管冷凍機やスターリング冷凍機に関しては 次第に実施されてきており, 内部現象の調査や設計のため のツールとして必要不可欠なものとなっている.

現在，地球温暖化などの環境問題に対応するために，太 陽光や廃熱を回収してそれらを動力源として利用する動き が高まりつつある。熱音響デバイスにおいても廃熱を利用 して振動流を発生させ, それを動力源として利用する方法 や発生した振動流により低温を発生させ，冷凍機として利 用する方法 ${ }^{8)}$ が検討されている. 上述したように，これま で実施された熱音響現象に関する数值解析は，パルス管冷

\footnotetext{
Received August 31, 2008

*1 北九州工業高等専門学校機械工学科

干 802-0985 福岡県北九州市小倉南区志井 5-20-1

Department of Mechanical Engineering, Kitakyushu National

College of Technology, 5-20-1 Shii, Kokuraminami-ku,

Kitakyushu, Fukuoka 802-0985, Japan

*2 九州大学大学院工学研究院機械工学部門

干 819-0395 福岡県福岡市西区元岡 744

Department of Mechanical Engineering, Kyushu University,

744 Motooka, Nishi-ku, Fukuoka 819-0395, Japan

*3 東覀大学大学院総合学術研究科

干751-8503 山口県下関市一の宮学園町 2-1

Graduate School of Integrated Science and Art,

University of East Asia, 2-1 Ichinomiyagakuen-cho,

Shimonoseki, Yamaguchi 751-8503, Japan

† E-mail: kosimizu@kct.ac.jp
}

凍機やスターリング冷凍機などの境界条件として圧力振動 を与えた場合の数值解析がほとんどであり，このように熱 を与えることで自励振動を発生させる過程を模擬する数值 解析の実施例は非常に少ない. しかしながら, 数值解析で は, 実際の実験では測定不可能なほど小さな圧力振幅の挙 動を調査することができたり, 測定機器が流れ場の挙動を 乱すことがないため, 自励振動発生時の管内の熱流動の詳 細を議論したり, 自励振動発生のための条件を調査するた めには, 数值解析の実施が非常に重要である.

野川らは, 熱音響発振器の周期的定常状態における数值 解析 ${ }^{9)}$ を実施し, その結果と実験結果との比較を行った結 果, 両者の定性的一致が得られたことを報告した. 今後, 管内の各種損失などを考慮することで定量的な一致が得ら れる可能性がある.

著者らはこれまで, 自励振動発生時のガスの挙動を詳細 に調査するために, 自励振動発生前の一様な圧力 ・温度場 の状態から自励振動が発生し, その振幅が増幅していく様 子を模擬する数值解析を実施してきた. 野川らの数值解析 との大きな違いは, 熱伝達率の設定の仕方であり, 野川ら の数值解析では時間的変動を考慮しているが, 著者らの数 值解析では一定值とした。一般的に, 熱伝達率の時間的変 動を考慮する場合は, 熱伝達率をヌセルト数から導出し, さらにヌセルト数をレイノルズ数の関数として設定するた め, 流速が 0 の状態では熱伝達率の值は 0 となる. そのた め, 意図的に流速を与えなければ加熱器から作動流体への 伝熱がおこらず, 自励振動は発生しない. 野川らの数值解 析は, 周期的定常状態を対象としており, 何らかの外乱を 与えることで自励振動を発生させ, 周期的定常状態を達成 
することが可能であるため，問題は起こらないが，著者ら の数值解析は, 上述したように, 自励振動発生時のガスの 挙動を調查することを目的として実施したため, 熱伝達率 の值を一定值とすることで, 初期の一様な圧力・温度場の 状態においても加熱器から作動流体への伝熱が起こるよう にした。しかしながら，振動流中における熱伝達率の設定 の仕方は未解決の問題であり, 今後の研究が期待される.

著者らが実施した数值解析において, 計算開始ととも に入熱量が一定値になるようなステップ状の入熱量条件を 与えた場合に, 初期に振動が発生し, その初期の振動がそ の後の自励振動発生に大きく影響することが確認されたた め, 本研究においては, ステップ状の入熱量を与えた場合 の初期のガスの挙動を詳細に調査した。実際の実験におい ては, 入熱量だけでなく, 自然界に存在するその他の外乱 も自励振動を誘発させるための条件になっていると考えら れる。しかしながら，外乱の影響が小さい場合（無重力下 や加圧された閉ループなど）でも，入熱量制御を行うこと で自励振動を発生できる可能性があるため, 入熱量の影響 を調查し，その基本的特性を把握することは非常に重要で あると考えられる，また，通常の実験では，ステップ状の 入熱量を与えることが多いと思われるが，本研究では，入 熱量のモード（変化のさせ方）によっては自励振動が発生 しない場合があることが確認されたため，入熱量の影響を より詳細にすることを目的として，その他の入熱量条件に おいての数值解析も実施した.

\section{2. 計算モデル}

熱音響現象を試験管などで最も簡単に実現することがで きる実験装置を Fig. 1 に示す。管内に蓄熱器（スチール ウールや金属メッシュなどの伝熱面積の大きなもの）を閉 端側寄りに挿入し, その蓄熱器閉端側端部を加熱すること で蓄熱器両端に温度差が形成されると自励振動（音）が発 生する. 本研究では, このような簡単な実験装置をとりあ げ，それをモデル化した。

計算モデルを Fig. 2 に示す. 計算モデルは, 長さ 180 $\mathrm{mm}$, 直径 $18 \mathrm{~mm}$ の円管とし, その内部に蓄熱器として金 属メッシュを挿入したものを想定した. Fig. 2 の計算モデ ルにおいて, 左端はガスが自由に出入りできる開端, 右端 は閉端とした。なお, 閉端の管壁は断熱壁とした。蓄熱器 は, 長さ $40 \mathrm{~mm}$ とし, 閉端側の空間の長さが $40 \mathrm{~mm}$ にな るように固定した。計算においては, 蓄熱器の伝熱面積,

質量および空隙率が必要であるが，それらの值は実際の実 験装置から導出し, 計算条件に取り込んだ。蓄熱器の両端 $10 \mathrm{~mm}$ は熱交換器とみなし, 左端を冷却器, 右端を加熱 器とした (以降, 蓄熱器, 加熱器, 冷却器を明確に区別す るために, 中央の $20 \mathrm{~mm}$ の部分のみを蓄熱器と呼び, 両 端 $10 \mathrm{~mm}$ の部分はそれぞれ加熱器, 冷却器と呼ぶ) . 冷 却器は水泠による泠却を行うことを想定し, 温度一定の条

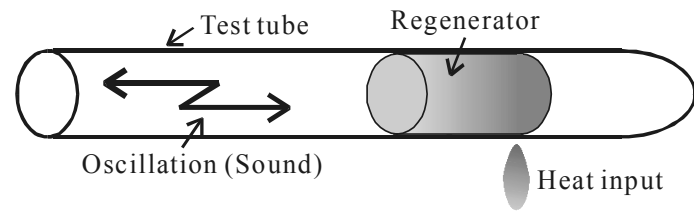

Fig. 1 Thermoacoustic phenomenon.

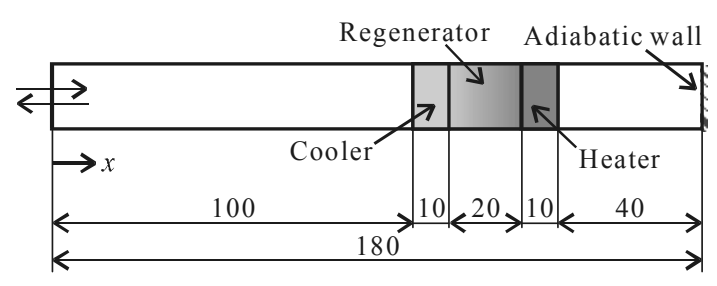

Fig. 2 Physical model.

Table 1 Initial conditions

\begin{tabular}{|c|c|c|c|c|}
\hline \multirow{2}{*}{ Pressure } & \multicolumn{3}{|c|}{ Temperature } & \multirow{2}{*}{ Velocity } \\
\cline { 2 - 4 } & Gas & Regenerator & $\begin{array}{c}\text { Heat } \\
\text { exchangers }\end{array}$ & \\
\hline $0.1 \mathrm{MPa}$ & $290 \mathrm{~K}$ & $290 \mathrm{~K}$ & $290 \mathrm{~K}$ & $0 \mathrm{~m} / \mathrm{s}$ \\
\hline
\end{tabular}

Table 2 Boundary conditions

\begin{tabular}{|c|c|c|}
\hline & Open end (Left) & Closed end (Right) \\
\hline Pressure & $0.1 \mathrm{MPa}$ & Wall condition \\
\hline Temperature & $290 \mathrm{~K}$ & Adiabatic condition \\
\hline Velocity & $0 \mathrm{~m} / \mathrm{s}$ & $0 \mathrm{~m} / \mathrm{s}$ \\
\hline
\end{tabular}

件とした．一方，加熱器はヒーターによる加熱を想定し， ガスに与える熱量を制御した。作動ガスは空気とし, 固体 壁との熱交換は蓄熱器, 加熱器および冷却器内でのみ考慮 した.

計算における初期条件および境界条件を Table 1 および Table 2 にそれぞれ示す. 初期条件は, 大気圧・常温の状 態とし, 圧力 $0.1 \mathrm{MPa}$, 温度 $290 \mathrm{~K}$ とした. また, 管外部

（管左端より左側）の領域では, 初期条件と同様の状態が 保たれると仮定し, 圧力 $0.1 \mathrm{MPa}$, 温度 $290 \mathrm{~K}$ の境界条件 を管左端で与えた。

\section{3. 基礎式}

ガスは理想気体とし, その流れを 1 次元流と仮定した. また，基礎式においては，ガスの圧縮性を考慮し，重力の 影響および粘性摩擦を無視した. 以下にガスに対する基礎 式を示す.

$$
\begin{aligned}
& \frac{\partial \rho}{\partial t}+\frac{\partial(\rho u)}{\partial x}=0 \\
& \frac{\partial(\rho u)}{\partial t}+\frac{\partial\left(\rho u^{2}+p\right)}{\partial x}=0
\end{aligned}
$$




$$
\frac{\partial(\rho e)}{\partial t}+\frac{\partial(\rho e u+p u)}{\partial x}-Q=0
$$

ここで, $\rho$ は密度, $t$ は時間, $u$ は流速, $x$ は軸方向距離, $p$ は圧力, $e$ は内部エネルギーと運動エネルギーの和を示 す.また, 式(3)の $Q$ は式(4)に示すように, ガスの熱伝導 による熱量および固体壁（蓄熱器, 加熱器および冷却器) との交換熱量を意味する。

$$
Q=\lambda \frac{\partial^{2} T}{\partial x^{2}}+\alpha A^{\prime}\left(T_{s}-T\right)
$$

ここで， $\lambda$ はガスの熱伝導率， $T$ はガスの温度， $\alpha$ は熱伝 達率, $A^{\prime}$ 'は単位体積あたりの固体壁の伝熱面積, $T_{s}$ は固体 壁の温度を示す.また, 式(4)の右辺第 2 項は蓄熱器, 加熱 器および冷却器内でのみ考慮する. 熱伝達率の值は, 経験 式 ${ }^{10)}$ 利用することで導出し，一定値として与えた.

ガスの計算に関しては, 式(1)〜(3)の保存則の他に次式に 示寸理想気体の状態方程式を使用寸る.

$$
p=\rho R T
$$

ここで，Rはガス定数を示す.

蓄熱器の温度変化は, 以下のエネルギーの式より導出す る.

$$
c m_{s} \frac{\partial T_{s}}{\partial t}+\alpha A\left(T-T_{s}\right)=0
$$

ここで, $c$ は蓄熱器の比熱, $m_{s}$ は蓄熱器の質量, $A$ は蓄熱 器の伝熱面積を示寸.

以上の基礎式において, 式(1)〜(3)の対流項は 1 次精度の 風上型 TVD スキーム, 式(4)の右辺第 1 項は 2 次精度の中 心差分により差分化を行った．式(1)〜(3)のガスの計算およ び式(6)の蓄熱器の計算における時間積分には, ルンゲ・ クッタ法を適用した。なお，計算格子の空間刻み $\Delta x$ は 0.5 $\mathrm{mm}$ とし, 時間積分の際の時間刻み $\Delta t$ は $10^{-6} \mathrm{~s}$ とした。

計算手順は，ガスおよび蓄熱器の計算を同時に時間発展 させ, ガスの計算においては密度, 流速および内部エネル ギーと運動エネルギーの和を，蓄熱器の計算においては温 度を導出する。なお，運動エネルギーと内部エネルギーの 和は式(7)のように表せるため, 式(7)より圧力を導出する.

$$
e=\frac{p}{\rho(\kappa-1)}+\frac{1}{2 \rho} u^{2}
$$

ここで， $\kappa$ は比熱比を示す．さらに，圧力を導出後，式(5) を用いて温度を導出する。よって, 1 ステップの時間発展 後に導出される物理值は, 密度, 流速, 圧力および温度の 值となる。蓄熱器の計算においては，式(6)からも明らかな ように, 蓄熱器内部の熱伝導は考慮しておらず, ガスとの 熱交換のみを考慮して各計算格子の温度を決定している.

自励振動が発生しない場合には，自励振動が発生しない まま圧力および温度が収束に向かうことが確認された時点 で計算を終了した。自励振動が発生する場合には，圧力振 幅および 1 周期の時間平均温度を 10 秒間隔で調查し，そ の相対誤差が $10^{-4}$ 以内に収まった時点で周期的定常状態に
Table 3 Properties and other values

\begin{tabular}{|c|c|}
\hline Thermal conductivity of gas & $0.02548 \mathrm{~W} /(\mathrm{m} \cdot \mathrm{K})$ \\
\hline Specific heat of the regenerator & $383 \mathrm{~J} /(\mathrm{kg} \cdot \mathrm{K})$ \\
\hline Gas constant & $288.6 \mathrm{~J} /(\mathrm{kg} \cdot \mathrm{K})$ \\
\hline Mass of the regenerator & $0.021 \mathrm{~kg}$ \\
\hline Specific heat ratio & 1.402 \\
\hline Heat transfer coefficient & $60 \mathrm{~W} /\left(\mathrm{m}^{2} \cdot \mathrm{K}\right)$ \\
\hline Heat transfer area of the regenerator & $0.186 \mathrm{~m}^{2}$ \\
\hline $\begin{array}{c}\text { Heat transfer area per unit volume } \\
\text { of the regenerator }\end{array}$ & $23763 \mathrm{~m}^{2} / \mathrm{m}^{3}$ \\
\hline
\end{tabular}

達したとみなし，計算を終了した。

計算に必要な物性值は, 初期圧力および初期温度での值 とした。それらの值およびそれら以外の計算に必要な值を

Table 3 に示寸.

\section{4. 計算結果}

\section{1 入熱量一定条件}

入熱量一定条件では，計算開始と同時に一定值となるス テップ状の入熱量条件とした。なお，事前の調查におい

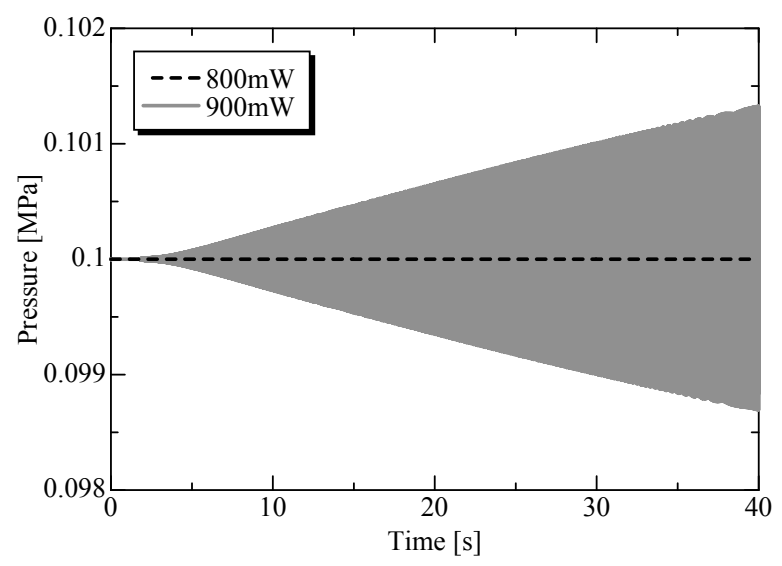

(a) Pressure changes from $t=0 \mathrm{~s}$ to $40 \mathrm{~s}$.

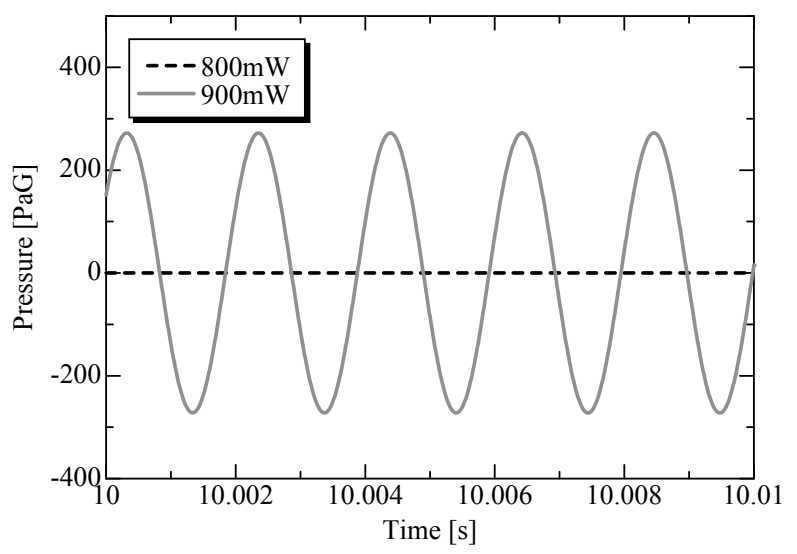

(b) Enlarged figure from $t=10 \mathrm{~s}$ to $10.01 \mathrm{~s}$.

Fig. 3 Pressure changes under the condition of constant heat input. 


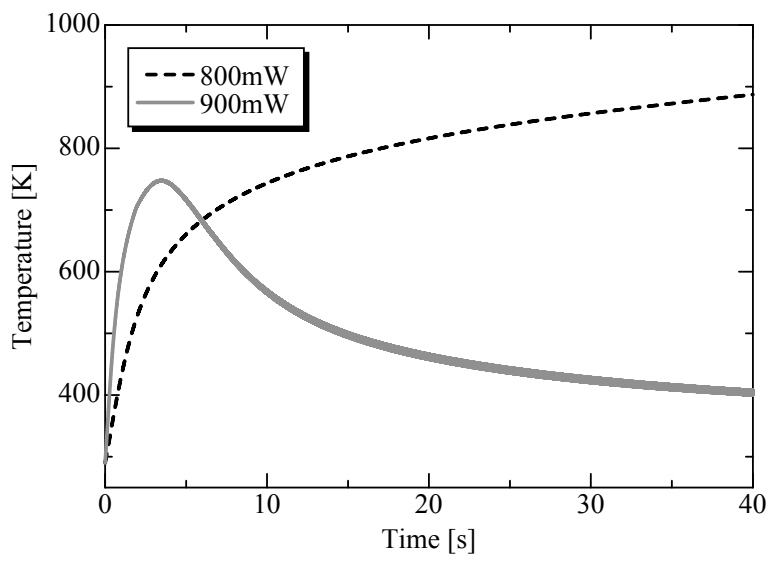

Fig. 4 Temperature changes from $t=0 \mathrm{~s}$ to $40 \mathrm{~s}$ under the constant heat input condition.

て，入熱量を $100 \mathrm{~mW}$ ずつ変化させて自励振動が発生する かしないかを調查した結果， $800 \mathrm{~mW}$ までは自励振動が発 生せず, $900 \mathrm{~mW}$ で自励振動が発生したため, 自励振動が 発生しない条件として $800 \mathrm{~mW}$ を, 自励振動が発生する条 件として $900 \mathrm{~mW}$ を選定した.

$800 \mathrm{~mW}$ および $900 \mathrm{~mW}$ の入熱量一定条件における $x=$ $160 \mathrm{~mm}$ (閉端側空間の中間部) の位置でのガスの圧力変化 を Fig. 3 に示す. Fig. 3(a)は，計算開始から 40 秒後までの 変化の様子を示しているが，その時間スケールが長いため に振動波形が接近し，非常に確認しにくい状態であるた め, Fig. 3(b)にその一部分 $(t=10 \mathrm{~s}-10.01 \mathrm{~s})$ を拡大した図 を示す。なお，圧力振幅が非常に小さいため，圧力の単位 はPa とし，ゲージ圧で表示した. 図より，800 mW の条件 では，自励振動が発生しておらず，ほぼ一定值となってい る様子が確認できる。一方，900 mW の条件では，計算開 始から数秒後に自励振動が発生しており，時間の経過とと もにその振幅が大きくなっている様子が確認できる。な お, Fig. 3(b)より, 振動の周波数は約 $500 \mathrm{~Hz}$ であることが わかるが，本計算モデルと同寸法の Fig. 1 の実験装置にお いても，実際に約 $500 \mathrm{~Hz}$ の周波数が発生することを確認済 みであり，本数值解析の結果が実際の現象をよく模擬でき ていることがわかる。

入熱量一定条件におけるガスの温度変化を Fig. 4 に示 す. なお, 図に示した温度変化は, $x=135 \mathrm{~mm}$ (加熱器中 間部）の位置での温度変化とし，計算開始から 40 秒後ま での変化の様子を表示してある。図より，800 mW の条件 では，時間の経過とともにガスの温度が上昇している様子 が確認できる。一方， $900 \mathrm{~mW}$ の条件では，ガスの温度が 計算初期には上昇し, 計算開始から約 4 秒後には低下し始 めている様子が確認できる． $800 \mathrm{~mW}$ の条件では，自励振 動が発生していないために，ガスがあまり動くことができ ず，熱伝導でのみしか熱が伝わらないため，加熱器付近の ガスがかなり高温まで温められていると考えられる。一

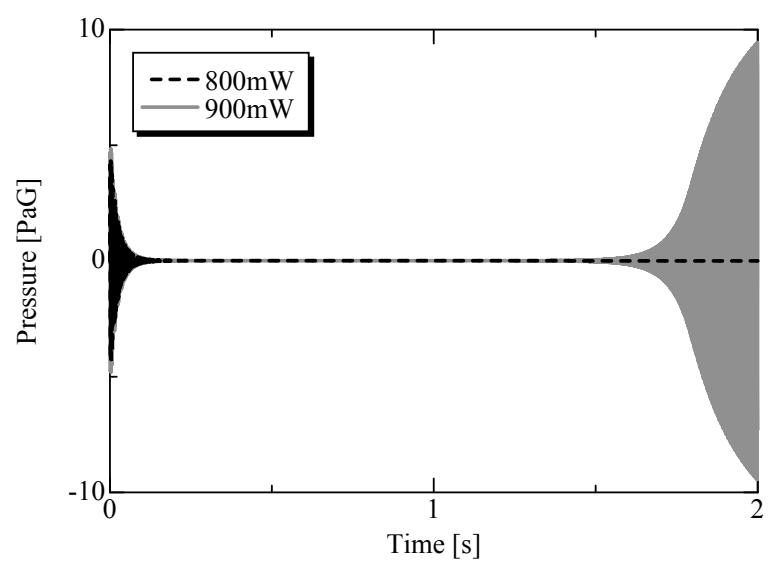

(a) Pressure changes from $t=0 \mathrm{~s}$ to $2 \mathrm{~s}$.

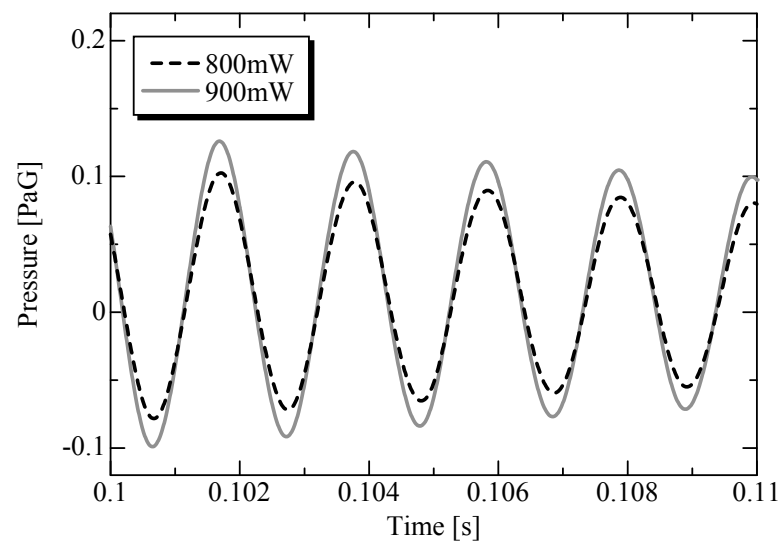

(b) Enlarged figure from $t=0.1 \mathrm{~s}$ to $0.11 \mathrm{~s}$.

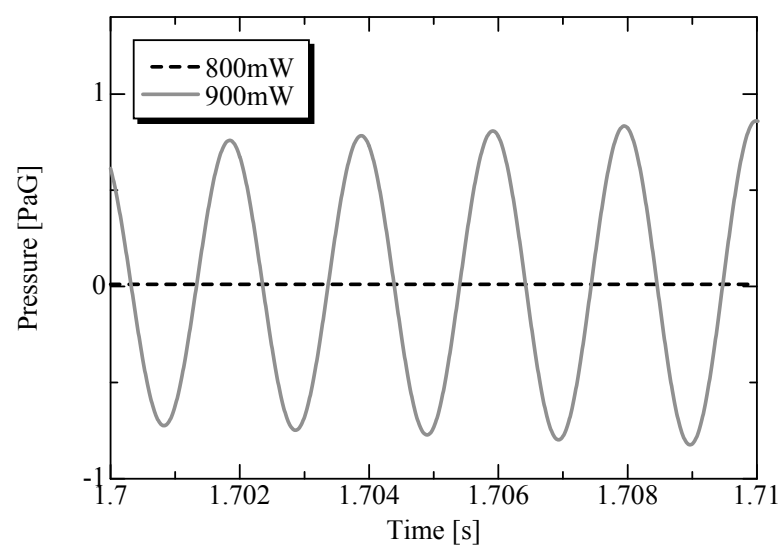

(c) Enlarged figure from $t=1.7 \mathrm{~s}$ to $1.71 \mathrm{~s}$.

Fig. 5 Initial pressure changes under the constant heat input condition.

方, $900 \mathrm{~mW}$ の条件では, 初期には自励振動が発生してい ないためガスの温度は上昇しているが，その後自励振動が 発生し, その振幅が大きくなっていくため, 加熱器からの 熱が激しく振動しているガスに伝えられるようになり，加 
熱器自体の温度が低下寸ると考えられる.

自励振動発生時の様子をより詳細にするために, Fig. 3(a)に示した圧力変化の初期の変化の様子を拡大表示した 図を Fig. 5 に示す. Fig. 5(a)は，計算開始から 2 秒後までの 変化の様子を示しているが，この時間スケールにおいても 振動波形が接近し, 非常に確認しにくい状態であるため, さらに初期の圧力振動の様子（ $t=0.1 \mathrm{~s}-0.11 \mathrm{~s} ）$ を拡大し たものを Fig. 5(b)に, $900 \mathrm{~mW}$ の条件において一端振動が 減衰して再び増幅する時の圧力振動の様子（ $t=1.7 \mathrm{~s}-1.71$ s）を拡大したものを Fig. 5(c)に示す. なお, Fig. 3(b)と同 様に, 圧力振幅が非常に小さいため, 圧力の単位は $\mathrm{Pa}$ と し，ゲージ圧で表示した. 図より，Fig. 3(a)では確認するこ とができなかったが, どちらの入熱量の場合でも初期に微 小振幅の振動が発生している様子が確認できる．最終的に 自励振動が発生しない $800 \mathrm{~mW}$ の条件では, この初期の振 動は減衰してしまうが, 自励振動が発生する $900 \mathrm{~mW}$ の条 件では, 一度は振動は減衰するが, その後再び振動が発生 し，増幅している様子が確認できる。しかしながら，自励 振動が発生する場合と発生しない場合の明確な違いを確認 することができないため, 初期の振動が減衰したと思われ る部分をさらに大きく拡大表示した図を Fig. 6 に示す. 図 より, $900 \mathrm{~mW}$ の条件では, Fig. 3 および Fig. 5 では確認す ることができなかった微小振幅の振動が初期の振動から継 続して起こっていることがわかる. 一方, $800 \mathrm{~mW}$ の条件 では，初期の振動は減衰していることがわかる．このた め, 自励振動が発生するという現象は, 初期の微小振幅の 振動が継続し, その振幅が増幅することを意味し, 自励振 動が発生しないという現象は, 初期の振動が減衰してしま うことを意味すると考えられる。

Fig. 5(b)，Fig. 5(c)および Fig. 6 のすべての図より，振動 の周波数は約 $500 \mathrm{~Hz}$ であることわかる.ささらに, Fig. 5(b) より, $800 \mathrm{~mW}$ および $900 \mathrm{~mW}$ の両条件における振動の様 子を比較すると, その周波数に違いはなく, 振幅の大きさ に違いがあることがわかる．よって，入熱量は振動の周波 数には影響せず, その振幅に大きく影響するということが わかる。

\section{2 入熱量変動条件 (直線的変動条件)}

計算開始とともに一定量の入熱量を与えることが，初期 の自励振動を誘発する外乱になっている可能性があるた め, 本条件においては目標の入熱量になるまで入熱量を少 しずつ増加させる条件を設定し，計算を実施した．Fig. 7 に入熱量変動条件（直線的変動条件）における加熱器での 入熱量の変化を示す. 本条件における入熱量は, 計算開始 と同時に直線的に増加させ， 2 秒後に $800 \mathrm{~mW}$ および 900 $\mathrm{mW}$ の入熱量にそれぞれ到達するようにし, その後は一定 值となるように設定した。

Fig. 7 に示したそれぞれの入熱量変動条件におけるガス の圧力変化を Fig. 8 に示す. なお, 図に示した圧力変化

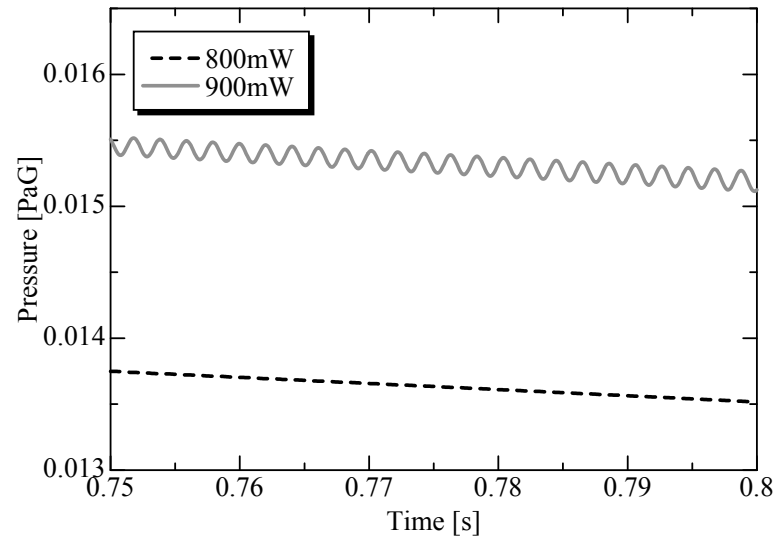

Fig. 6 Enlarged figure of the pressure changes from $t=0.75$ $\mathrm{s}$ to $0.8 \mathrm{~s}$ under the constant heat input condition.

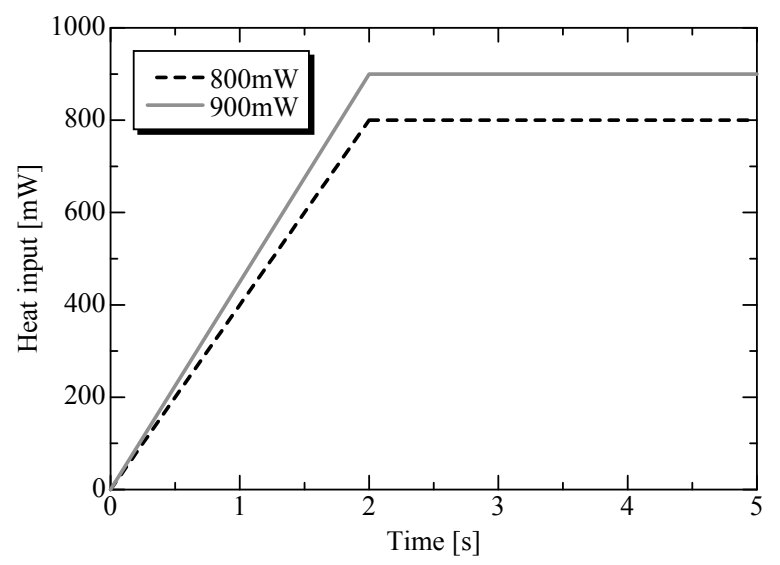

Fig. 7 Linear heat input change condition.

は， $x=160 \mathrm{~mm}$ の位置での圧力変化とした. Fig. 8(a)は, 計算開始から 3 秒後までの変化の様子を示しているが, Fig. 3(a)および Fig. 5(a)と同様に, 振動波形が接近し, 非常 に確認しにくい状態であるため, 初期の圧力振動の様子（ $t$ $=0.01 \mathrm{~s}-0.02 \mathrm{~s} ）$ を拡大したものを Fig. 8(b)に，計算開始か ら 2 秒後に発生する圧力振動の様子 $(t=1.995 \mathrm{~s}-2.005 \mathrm{~s})$ を拡大したものを Fig. 8(c)に示す. 図より, $800 \mathrm{~mW}$ および $900 \mathrm{~mW}$ の両条件ともに, 初期に微小振幅の振動が発生し ているが，その後一旦は振動が減衰し, 計算開始から 2 秒 後に再び振動が発生していることがわかる. 初期の振動 は, 入熱量一定条件の場合と比較すると, その振幅がかな り小さくなっており, 入熱量を少しずつ増加させた効果が 確認できるが, 入熱量一定条件の時には自励振動が発生し なかった $800 \mathrm{~mW}$ の条件において, 本条件では最終的に自 励振動が発生することが確認された。本条件においても, 初期に振動が発生していることから，入熱量が与えられて いない平衡状態のモードから入熱量が加わるというモード へ変化することが自励振動を誘発させる外乱になっている と考えられる. 同様に, 計算開始から 2 秒後の時にも, 入 


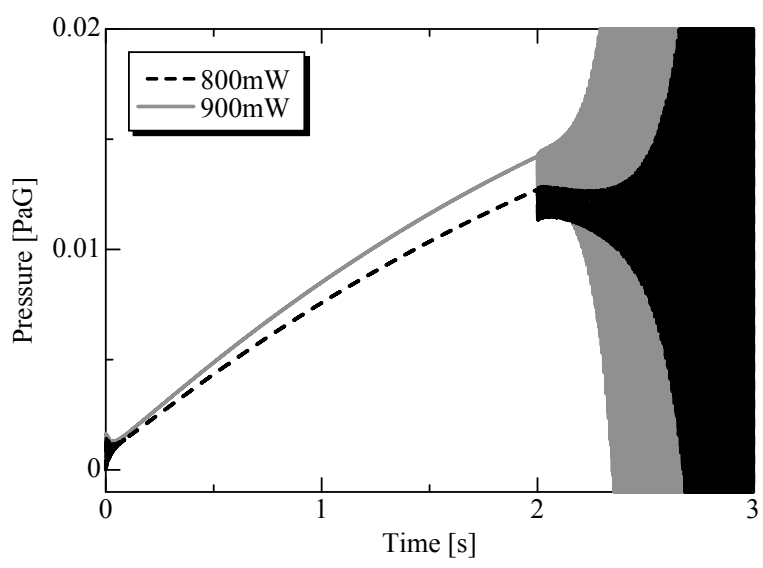

(a) Pressure changes from $t=0 \mathrm{~s}$ to $3 \mathrm{~s}$.

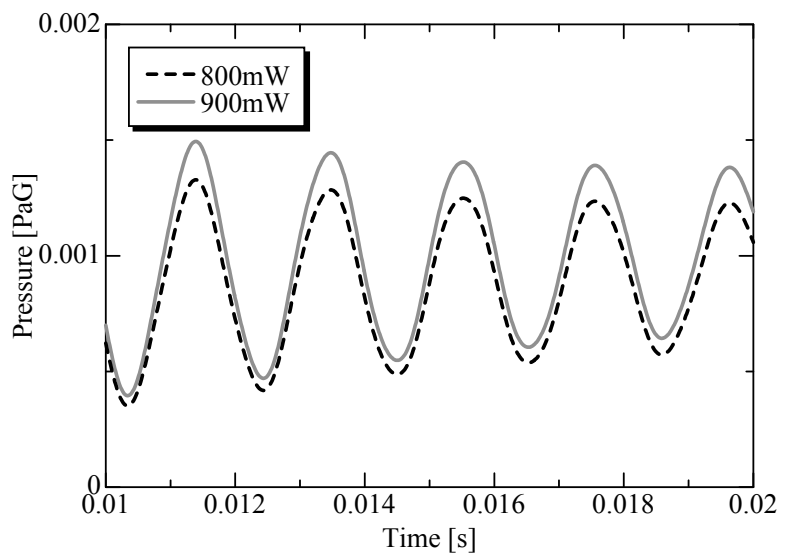

(b) Enlarged figure from $t=0.01 \mathrm{~s}$ to $0.02 \mathrm{~s}$.

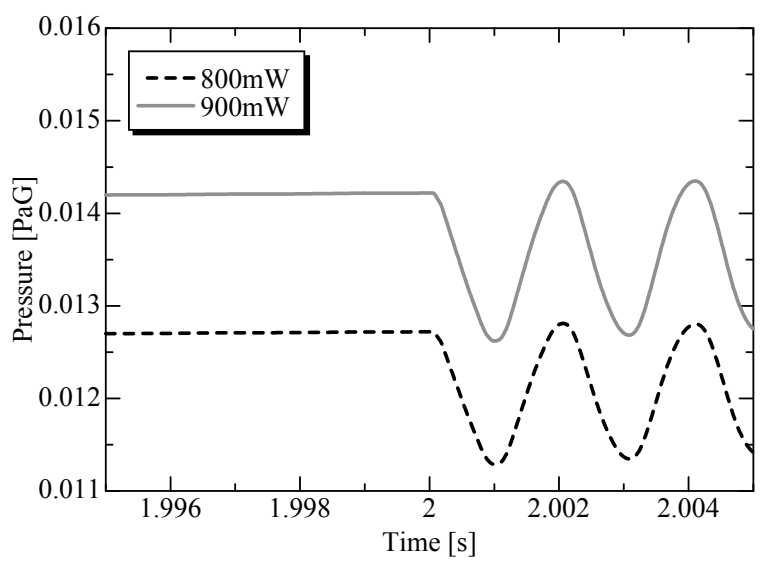

(c) Enlarged figure from $t=1.995 \mathrm{~s}$ to $t=2.005 \mathrm{~s}$.

Fig. 8 Pressure changes under the linear heat input change condition.

熱量が一定の割合で増加しているモードから一定值のモー ドへと変化することが自励振動を誘発させる外乱になって いると考えられる.さらに，Fig. 9 に $800 \mathrm{~mW}$ の入熱量一 定条件および入熱量変動条件（直線的変動条件）における

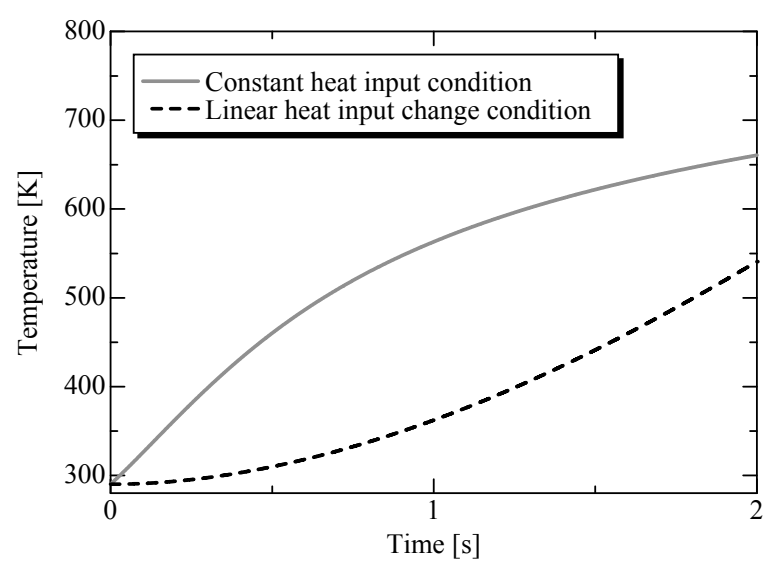

Fig. 9 Temperature changes under the constant heat input condition and linear heat input change condition.

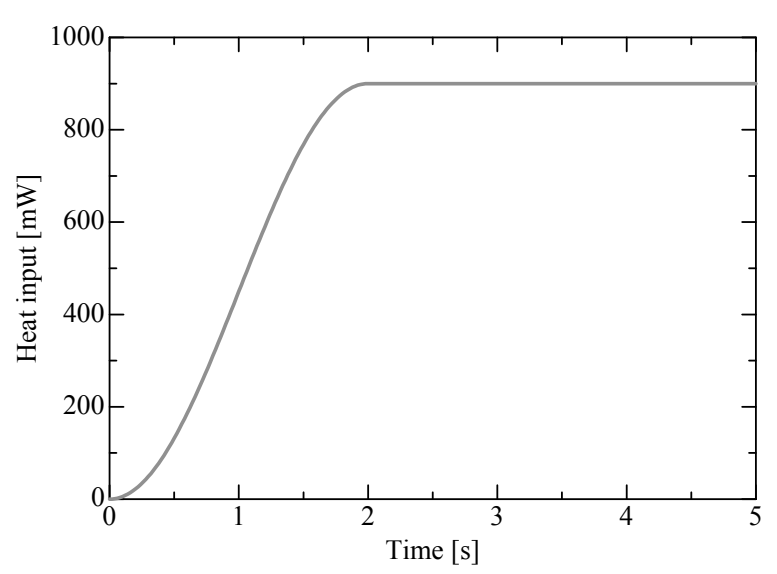

Fig. 10 Sinusoidal heat input change condition.

$x=135 \mathrm{~mm}$ の位置での温度変化を示すが，本条件において は, 計算開始から 2 秒後には加熱器の温度は高温になって おり, 運転条件として十分な蓄熱器両端の温度差が形成さ れていたと考えられる. 一方, 入熱量一定条件において は, 計算開始時には加熱器の温度は上昇しておらず, 自励 振動を誘発させる外乱があったとしても運転条件として必 要な蓄熱器両端の温度差が形成されていないために, 初期 の振動は減衰し, その後の本格的な自励振動に至らなかっ たと考えられる。

\section{3 入熱量変動条件 (正弦波的変動条件)}

入熱量のモード変化が, 自励振動を誘発させる外乱に なっていることが確認されたため, 本条件においては目標 の值になるまで入熱量を緩やかに増加させる条件を設定 し, 計算を実施した. Fig. 10 に入熱量変動条件（正弦波的 変動条件）における加熱器での入熱量の変化を示す. 本条 件における入熱量は, 計算開始と同時に正弦波的に増加さ せ， 2 秒後に $900 \mathrm{~mW}$ の入熱量に到達するようにし，その 後は一定值となるように設定した.

Fig. 10 に示した入熱量変動条件におけるガスの圧力変化 


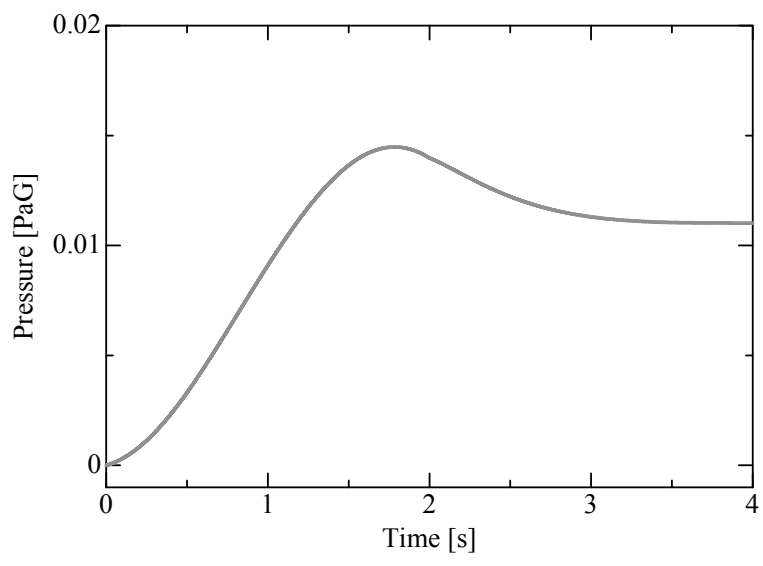

Fig. 11 Pressure change from $t=0 \mathrm{~s}$ to $4 \mathrm{~s}$ under the sinusoidal heat input change condition.

を Fig. 11 に示す. なお, 図に示した圧力変化は, $x=160$ $\mathrm{mm}$ の位置での圧力変化とし, 計算開始から 4 秒後までの 変化の様子を表示してある。図より, 圧力変化は起こって いるものの，自励振動は発生していない様子が確認でき る.このため，入熱量の急激なモード変化がなければ，外 乱的要因とはならず，自励振動は発生しないことがわか る.

\section{5. 結 言}

熱音響現象における自励振動発生時のガスの挙動を詳細 に調査することおよび自励振動発生に対する入熱量の大き さおよびモード（入熱量の変化のさせ方）の影響を明確に することを目的として，数值解析を実施した結果，以下の 結論を得た。

（1）入熱量が時間的に不連続であれば，自励振動を誘発 させるための外乱的要因となる。

（2）入熱量制御により初期に発生した微小振幅の振動が 継続し，やがて大きく増幅すれば本格的な自励振動 が発生したことを意味し，減衰してしまえば自励振 動が発生しなかったことを意味する。

（3）入熱量を正弦波的に緩やかに変化させると，微小振 幅の自励振動は発生せず，外乱的要因とはならな い.

実際の実験において, 約 $500 \mathrm{~Hz}$ の自励振動を確認した実 験装置をモデル化し，実施した数值解析の結果からも約 $500 \mathrm{~Hz}$ の自励振動を確認することができたため, 本数值解 析が実際の現象を定量的によく模擬できていると考えるこ とができる。しかしながら，本数值解析では，蓄熱器の熱 伝導や蓄熱器, 加熱器および冷却器以外の場所でのガスと 固体壁の熱交換などを考慮していないため，ガスおよび固 体壁の温度に関しては，実際の実験と定量的な差があるこ とが予想される。これらの熱的条件を検討し，実験結果と の比較を行うことが今後の課題である.

\section{参 考 文 献}

1）富永 昭: 「熱音響工学の基礎」, 内田老鶴戋, 東京 (1998)

2) Y. Tashiro, T. Biwa and T. Yazaki: "Measurement of temperature oscillation by using a thermocouple," Proceedings of the 9th Symposium on Stirling Cycle (2005) 63-64 (in Japanese)

田代雄亮, 琵琶哲志, 矢崎太一: 熱電対を用いた温度変動 の測定」, 第 9 回スターリングサイクルシンポジウム講演論 文集 (2005) 63-64

3) Y. Hozumi, M. Murakami and Y. Yoshizawa: "Numerical study of pulse-tube flow," TEION KOGAKU 33 (1998) 200-206 (in Japanese)

穂積良和, 村上正秀, 吉澤能政 :「パルス管内流動の数值計 算」, 低温工学 33 (1998) 200-206

4) M. Nogawa, S. Zhu and T. Inoue: "Study of capabilities on stirling refrigerator with pulse tube," Proceedings of the 5th Symposium on Stirling Cycle (2001) 129-132 (in Japanese)

野川正文, 朱 紹偉, 井上龍夫 : 「パルス管型スターリング 冷凍機の可能性の検討」, 第 5 回スターリングサイクルシン ポジウム講演論文集 (2001) 129-132

5) Y. Hiratsuka and H. Morishita: "Numerical calculation for stirling type pulse tube cryocooler -Examination of phase shifter-," Proceedings of the 6th Symposium on Stirling Cycle (2002) 117120 (in Japanese)

平塚善勝, 森下弘之 : 「スターリング型パルス管冷凍機の数 值計算一位相制御機構の検討一」, 第 6 回スターリングサイ クルシンポジウム講演論文集 (2002) 117-120

6) T. Koshimizu, H. Kubota, Y. Takata and T. Ito: "Numerical analysis of heat and fluid flow in a basic pulse-tube refrigerator Analysis on heat exchange between the tube wall and the working gas-," TEION KOGAKU 38 (2003) 339-347 (in Japanese) 小清水孝夫, 久保田裕巳, 高田保之, 伊藤猛宏 :「ベーシッ ク型パルス管冷凍機における熱流動数值解析一管壁と作動 ガスの熱交換に関する解析一」, 低温工学 38 (2003) 339-347

7) T. Koshimizu, H. Kubota, Y. Takata and T. Ito: "Numerical analysis of heat and fluid flow in pulse tube refrigerator," Int. J. Numerical Methods for Heat \& Fluid Flow 15 (2005) 617-630

8) H. Hirano, S. Sakamoto, Y. Tsukane, H. Yoshida and Y. Watanabe: "Effect on the total length and the shape of the thermoacoustic cooling system," Proceedings of the 9th Symposium on Stirling Cycle (2005) 81-84 (in Japanese)

平野宏之, 坂本眞一, 塚根芳将, 吉田秀穂, 渡辺好章: 「熱 音響冷却システムの全長と形状が温度低下特性に与える影 響について」, 第 9 回スターリングサイクルシンポジウム講 演論文集 (2005) 81-84

9) M. Nogawa, S. Shu and T. Inoue: "Numerical simulation analysis of thermal acoustic generator,” Trans. Japan Soc. Mech. Eng., Ser. B 72 (2006) 1089-1094 (in Japanese)

野川正文, 朱 紹偉, 井上龍夫 : 「熱音響発振器の数值シ ミュレーション解析」, 日本機械学会論文集 B 編 72 (2006) 1089-1094

10) M. Tanaka, I. Yamashita and F. Chisaka: "Flow and heat transfer characteristics of Stirling engine regenerator in oscillating flow," Trans. Japan Soc. Mech. Eng., Ser. B 55 (1989) 2478-2485 (in Japanese) 
田中誠, 山下 巌, 千坂文武 :「往復流れ場に置かれたス ターリングエンジン用再生器材料の流動および伝熱特性」, 日本機械学会論文集 B 編 55 (1989) 2478-2485

小清水 孝 夫 1977 年 3 月生. 1999 年九州大学工学部機械 工学科卒業. 2004 年九州大学大学院工学府博士後期課程修了. 2004 年北九州工業高等専門学校勤務. 現在, 北九州工業高等専 門学校機械工学科講師。パルス管冷凍機, 熱音響現象の研究に従 事. 低温工学協会, 日本機械学会, 日本伝熱学会会員. 博士（工 学).

久保田 裕 巳 1947 年 8 月生. 1971 年九州大学工学部機械 工学科卒業. 1973 年九州大学大学院工学研究科修士課程修了. 1978 年九州大学工学部勤務. 現在, 九州大学大学院工学研究院 機械工学部門助教. 低温流体の沸騰伝熱, マイクロ冷凍機の研究
に従事. 低温工学協会, 日本機械学会, 日本伝熱学会会員. 博士 (工学).

高 田 保之 1956 年 4 月生. 1979 年九州大学工学部応用 原子核工学科卒業. 1984 年九州大学大学院総合理工学研究科博 士後期課程修了. 1984 年九州大学工学部勤務. 現在, 九州大学 大学院工学研究院機械工学部門教授. 相変化に及ぼす表面濡れ 性, マイクロ冷凍機の研究に従事. 低温工学協会, 日本機械学 会, 日本伝熱学会会員. 工学博士.

伊 藤 猛 宏 1939 年 1 月生. 1961 年九州大学工学部機械 工学科卒業. 1966 年九州大学大学院工学研究科博士後期課程単 位修得退学. 1966 年九州大学工学部勤務. 現在, 九州大学名誉 教授および東亜大学大学院総合学術研究科教授. 熱工学に関する 研究に従事. 低温工学協会, 日本機械学会, 日本伝熱学会, 日本 熱物性学会会員. 工学博士. 